\title{
Paleoparasitological remains revealed by seven historic contexts from "Place d'Armes", Namur, Belgium
}

\author{
Gino Chaves da Rocha/ ${ }^{+}$,Stephanie Harter- Lailheugue**, Matthieu Le Bailly**, \\ Adauto Araújo, Luiz Fernando Ferreira, Nicolau Maués da Serra-Freire*, \\ Françoise Bouchet**
}

Escola Nacional de Saúde Pública-Fiocruz, Rua Leopoldo Bulhões 1480, 21041-210 Rio de Janeiro, RJ, Brasil *Laboratório de Ixodides, Departamento de Entomologia, Instituto Oswaldo Cruz-Fiocruz, Rio de Janeiro, RJ, Brasil **Laboratoire de

Paléoparasitologie, Université de Reims, Reims, France

Human occupation for several centuries was recorded in the archaeological layers of "Place d'Armes", Namur, Belgium. Preventive archaeological excavations were carried out between 1996/1997 and seven historical strata were observed, from Gallo-Roman period up to Modern Times. Soil samples from cesspools, latrines, and structureslike were studied and revealed intestinal parasite eggs in the different archaeological contexts. Ascaris lumbricoides, A. suum, Trichuris trichiura, T. suis. Taenia $s p$., Fasciola hepatica, Diphyllobothrium $s p$., Capillaria $s p$. and Oxyuris equi eggs were found. Paleoparasitology confirmed the use of structures as latrines or cesspit as firstly supposed by the archaeologists. Medieval latrines were not only used for rejection of human excrements. The finding of Ascaris $s p$. and Trichuris sp. eggs may point to human's or wild swine's feces. Gallo-Roman people used to eat wild boar. Therefore, both A. suum and T. suis, or A. lumbricoides and $\mathrm{T}$. trichuris, may be present, considering a swine carcass recovered into a cesspit. Careful sediment analysis may reveal its origin, although parasites of domestic animals can be found together with those of human's. Taenia sp. eggs identified in latrine samples indicate ingestion of uncooked beef with cysticercoid larvae. F. hepatica eggs suggest the ingestion of raw contaminated vegetables and Diphyllobothrium sp. eggs indicate contaminated fresh-water fish consumption. Ascaris $s p$. and Trichuris sp. eggs indicate fecal-oral infection by human and/or animal excrements.

Key words: paleoparasitology - helminth eggs - paleoepidemiology - coprolites - ancient diseases

Artifacts, organic remains, and architectural structures found in different archaeological contexts help to understand aspects of lifestyle, diet, nourishment, economical features, as well as social and health conditions of ancient populations (Reinhard 1992, Plumier et al. 1997b, Bouchet et al. 2002). Paleoparasitological analyses contribute to elucidate which parasite infections prevailed in ancient populations and how these infections could affect humans and related synantropic potential animal reservoirs. One might take into account that both infection and disease is the product of a process where complex and dynamic host-parasite-ecological interactions are involved (Araújo \& Ferreira 2000, Araújo et al. 2003, Bouchet et al. 2003a).

Parasites and parasite DNA (Iñiguez et al. 2003, Bouchet et al. 2003a) can be recovered from ancient feces or coprolites (Buckland 1829). Parasites can also be recovered from the inside of mummified bodies, skin, fur, hair, and any other organic remain (Pike 1968, Ferreira et al. 1988, Aspöck et al. 1999). Organic sediments recovered from stratigraphical layers in the archaeological sites are

Financial supported: CNPq, Capes-Cofecub ${ }^{+}$Corresponding author: ginoroch@hotmail.com Received 20 July 2006

Accepted 16 October 2006 other sources to be analyzed for parasites. Sediments are formed by accumulation of a variety of anthropological or other source of material, including fecal material (Dommelier-Spejo 2001). Sediments are the product of mineral particles deposited from eroded rocks and stones carried by gravity, water influx, wind, or glaciations to somewhere along the time. Its composition, texture, and structure are the main characteristics studied by specialists (Hardesty 1977). Coprolites may be found in sediments, disintegrated or intact, depending on the degree of preservation (microenvironment) in a variety of deposits, and are recovered for analysis (Jones 1985, Bouchet et al. 2003a). Thus, helminth eggs can be found in organic sediments of archaeological deposits as latrines, cesspits and other structures (Wilke \& Hall 1975).

Paleoparasitological results are only available combined with archaeological data (Ferreira et al. 1983, Bouchet et al. 1999). On the other hand, they contribute to understand and confirm different functions of structure remnants, such as dumps, latrines or cesspools (Bouchet et al. 1997, 2000). Paleoparasitological complementary data help archeologists better interpreting structures in archaeological sites determining, for example, its earlier use as latrines, pits, pigsties, and others, used for breeding and cattle-shed (Bouchet \& Bentrad 1997, Bouchet et al. 2000). Therefore, the number and concentration of helminth eggs in the samples indicate fecal pollution. Eventually, the presence of host-specific parasites allows to confirm the zoological origin of the fecal material in the sediments (Bouchet 1994). 


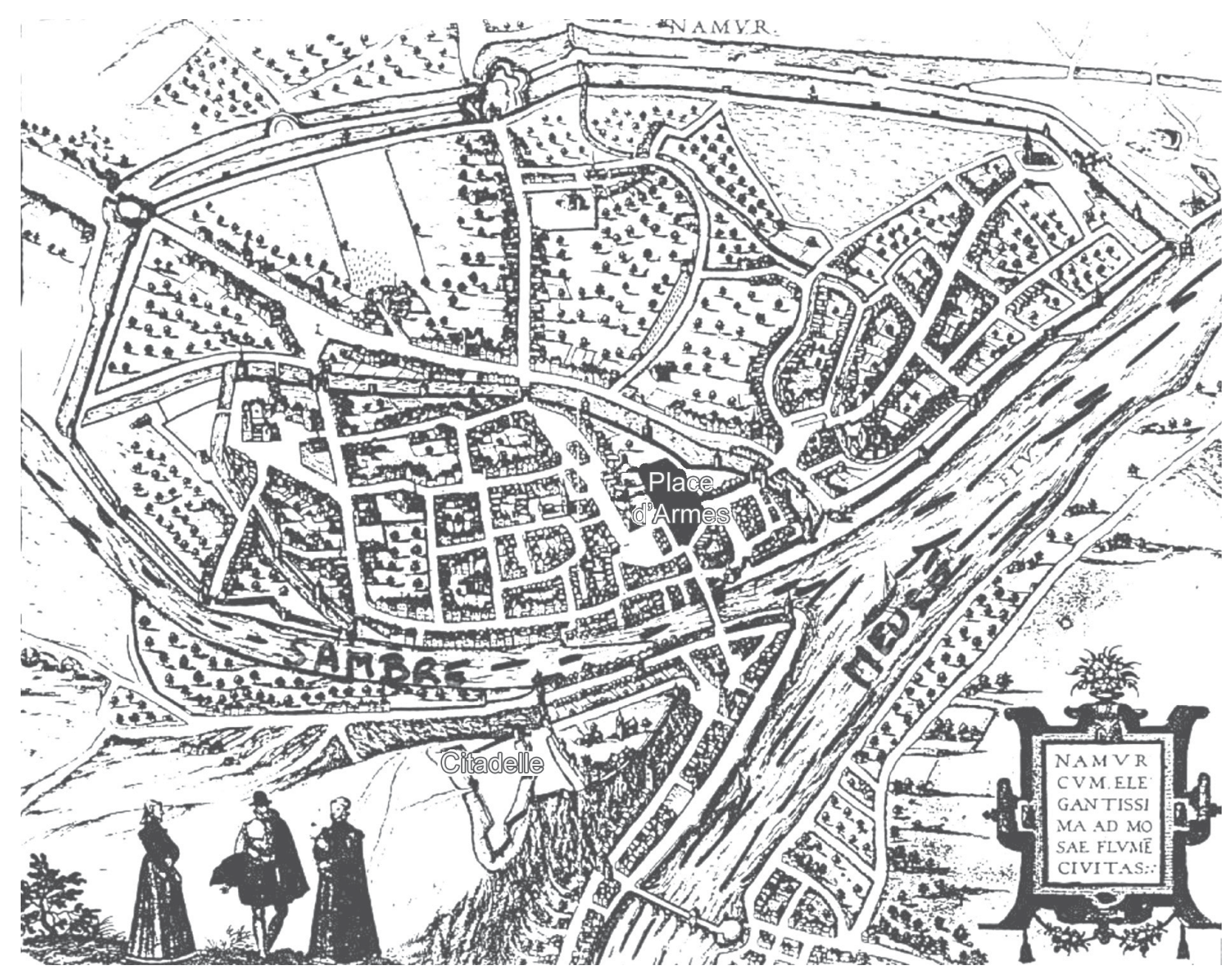

Fig. 1: Namur city plan showing the "Place d'Armes" and the fortress (Citadelle) in detail. Middle Age period. (from Plumier et al. 1997a).

The first findings of helminth eggs in sediments recovered from deposits, latrines, and structures-like were recorded by Szidat (1944), Taylor (1955), Grzywinsky (1960), Jansen and Over (1962, 1966), Specht (1963), Pike and Biddle (1966), and Pike (1967, 1968), mainly of the medieval period. The findings show that the major parasitic association found throughout time has been Ascaris sp. - Trichuris sp. (Taylor 1955, Jansen \& Over 1966, Pike \& Biddle 1966, Pike 1967, Wilke \& Hall 1975, Wilson \& Rackham 1976, Schia 1979, Greig, 1981, Jones 1982, Bouchet 1991a,b, 1995a,b, Han et al. 2003, Fernandes et al. 2005). A. lumbricoides and A. suum eggs are undistinguishable (Loreille \& Bouchet 2003), but the eggs of Trichuris species have morphometric patterns that allow specific diagnosis. Trichuris species are also very specific. Therefore, when $T$. trichiura eggs are identified other parasites associated in the same sample may also be inferred as human's parasites (Fernandes et al. 2005).

In this article, archaeological and paleoparasitological data are used to reconstruct behaviors in the past, and to understand how structures found in archaeological sites were used. To identify the origin of organic remains and parasites, if human's or other animal's, results were compared with the archaeologists' suppositions about the original function of the deposits or sanitary structures found at the Belgium "Place d'Armes" archaeological site. Based on these interpretations, a tentative approach to health conditions in the past is discussed.

\section{MATERIAL AND METHODS}

The site - Namur, capital of Wallonia Region and administrative seat of Namur Province, Belgium, is located at the confluence of the Meuse and Sambre rivers, which originate the Crognon River. At this strategic site the human presence is dated nearly the Neolithic period but the first real occupation, as a Gaulish village was established at that confluence before the Roman conquest. During the Roman occupation Namur was a Gallo-Roman "vicus"1 and the Meuse River had an important period of navigation. Along the Middle Age the city had well developed

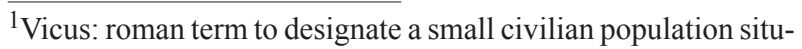
ated around of a military fort. 
and was protected by four large ramparts. At the end of $\mathrm{XV}$ century its fortifications were one of the ten most coveted in the Europe (Plumier \& Vanmechelen 1996). Therefore, the "Place d'Armes" of Namur was an important site of human settlement throughout the time at the region.

During the XIX century the Archaeological Society of Namur pointed out the evidences of a Gallo-Roman settlement (first third of the first century AD). A Roman vicus, a Merovingian necropolis and remains of the Middle Age were observed (Plumier et al. 1997a). Along 1996/1997 excavations were carried out at the "Place d'Armes" preparing the area for the building of an underground parking lot (Plumier \& Vanmechelen 1996, Plumier et al. 1997b).

The plans of the site, the stratigraphical layers of the structures, and sediments recovery - The archaeologists Jean Plumier, Nathalie Mess, and Raphaël Vanmechelen described the seven archaeological contexts present at the "Place d'Armes". They outlined the plans of the site and the stratigraphical strata of the deposits indicating exactly the layer of sediments that the samples were took from (Figs 2,3). They were collected from latrines and other structures built for domestic rejections. The sediments were very well preserved, albeit the superposition of buildings constructed throughout the centuries (Plumier et al. 1997a). The Middle-Age site of "Place d'Armes" presented excellent humid and anaerobic taphonomic conditions, (Loreille \& Bouchet 2003). Thirty-four samples

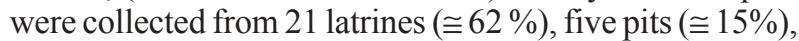

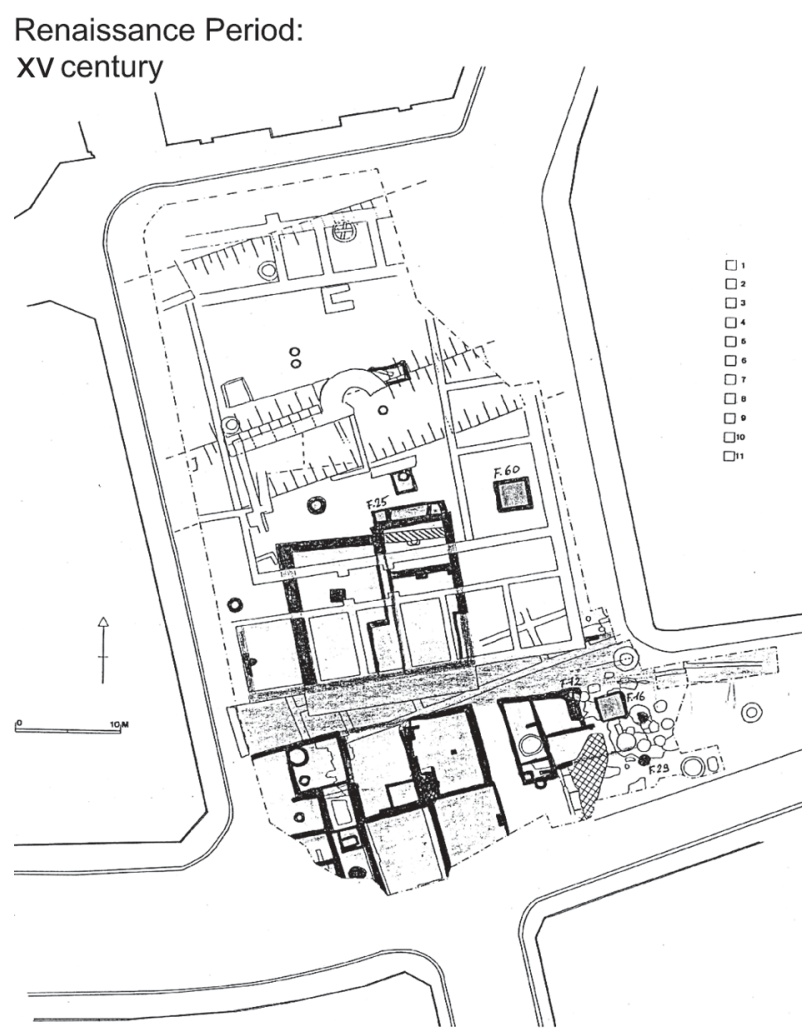

Fig. 2: an illustration presenting the plan of the site during the Renaissance Period settlement (Rocha 2003 adapted from Plumier et al. 1997a).

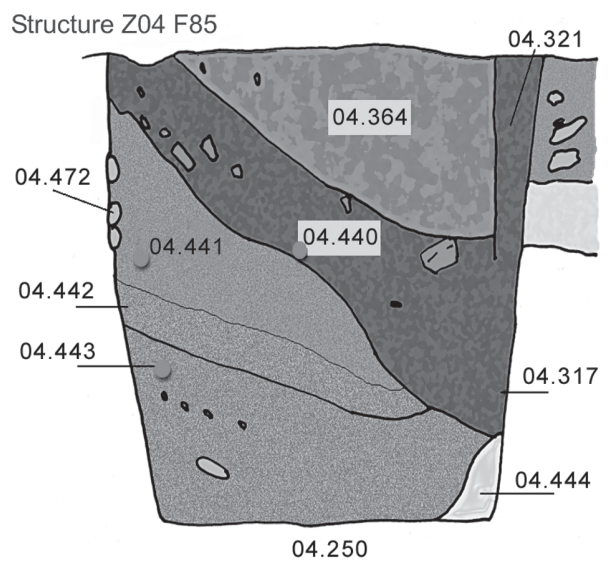

Fig. 3: one of the stratigraphical layers outlined to indicate the characteristics of the structure and the level (points in red) where the samples where recovered (Rocha 2003, adapted from Plumier et al. 1997a).

and eight structures such as pits, barrels and canalizations $(\cong 23 \%)$. The site contains archaeological records belonging to the Gallo-Roman period (2nd and 3rd centuries), the Middle-Age up to recent times (XIX Century).

The paleoparasitological analysis - The material was processed according to Bouchet et al. (1999). Samples were rehydrated for, at least, $72 \mathrm{~h}$ in the $0.5 \%$ aqueous trisodium phosphate solution (Callen \& Cameron 1960). A $5 \%$ glycerinated solution was added to reinforce the rehydration of more petrified elements. The material was then crushed in a mortar. The suspension was treated in an ultrasonic device (Sonorex $103 \mathrm{~K}$ ) at $60^{\circ} \mathrm{C}$ for $1 \mathrm{~min}$ under $3000 \mathrm{rpm}$ and strained through $315 \mu \mathrm{m}, 160 \mu \mathrm{m}, 50 \mu \mathrm{m}$, and $25 \mu \mathrm{m}$ meshes. The last two screenings were treated with flotation (densities 1.04 to 1.0 ) and sedimentation (1500 rpm for $5 \mathrm{~min}$ ) techniques. Twenty slides of each sample were examined, as recommended by standard procedures (Araújo et al. 1998). The images were registered and treated by the SAISAM Microvision Instruments program. Processed samples were stored into hemolysis tube with caps and preserved in $1 \mathrm{ml} 10 \%$ formalin solution to avoid microorganism development.

Helminth egg identification criteria were based on size, shape, characteristics of eggshell ornamentation, presence or not of operculum and polar plugs. Based upon these criteria the eggs were classified into the respective taxonomic levels for family, genus and species, even when the zoological origin of the fecal matter was unknown (Bouchet et al. 1989, 2000).

From 16 samples that presented a high concentration of trichurid eggs (over 50 eggs per slide) eight samples were randomly selected for statistical treatment to differentiate and establish the probable zoological source of the organic sediment.

\section{RESULTS}

Ascaris sp. and Trichuris sp. eggs were found throughout the settlement. Metric analysis of trichurid eggs 
presented values ranging in width (26.1 to $28.4 \mu \mathrm{m})$ and lenght (51 to $56.9 \mu \mathrm{m}$ ), as showed in Table I.

Morphometric comparisons were done with recorded data (Sondak 1948, Beer 1976, Confalonieri 1983, Sloss et al. 1994, Fernandes et al. 2005) especially for $T$. trichiura and T. suis, presented in Table II and III, to support the identification between these species of trichurids eggs.

The paleoparasitological findings of "Place d'Armes" site are presented in Table IV. We point out the parasite genus of the helminth eggs recovered along the considered archaeological periods. The type of the structures was defined by the archaeologists in accordance to their field descriptions (Plumier et al. 1997a).

\section{DISCUSSION}

Parasite eggs were found in all layers. Some parasite egg characteristics allowed identifying fecal zoological origin. Considering the parasitic spectrum (parasitic association) and the metric comparisons between human

TABLE I

Measurements of trichurid eggs ( $\mu \mathrm{m})$ found in Namur archaeological site "Place d'Armes", Belgium

\begin{tabular}{lccccc}
\hline & \multicolumn{2}{c}{ Width } & & \multicolumn{2}{c}{ Length } \\
\cline { 2 - 3 } \cline { 5 - 6 } Samples & Mean & CI 95\% & & Mean & CI 95\% \\
\hline 02.169 & 26.8 & $26.4-27.1$ & & 52.0 & $51.0-53.1$ \\
04.443 & 27.2 & $26.6-27.8$ & & 54.8 & $54.1-55.5$ \\
04.424 & 26.4 & $26.1-26.8$ & & 54.9 & $54.2-55.6$ \\
02.007 & 26.3 & $24.7-27.9$ & & 55.3 & $53.7-56.9$ \\
04.453 & 26.6 & $26.4-26.8$ & & 52.3 & $51.6-53.0$ \\
04.011 & 26.9 & $26.3-27.4$ & & 54.4 & $53.3-55.5$ \\
04.269 & 27.5 & $26.6-28.4$ & & 54.4 & $54.2-56.7$ \\
04.259 & 27.0 & $26.5-27.5$ & & 54.2 & $52.9-55.4$ \\
\hline
\end{tabular}

TABLE II

Measurements of Trichuris trichiura eggs $(\mu \mathrm{m})$ registered by other authors

\begin{tabular}{lccllc}
\hline & \multicolumn{2}{c}{ Width } & & \multicolumn{2}{c}{ Length } \\
\cline { 2 - 3 } \cline { 5 - 6 } Authors & Mean & CI 95\% & & Mean & CI 95\% \\
\hline Dinnik (1938) & 26.8 & $22.5-30.0$ & & 57.8 & $50.0-65.0$ \\
Sondak (1948) & 25.6 & $24.0-29.0$ & & 56.7 & $54.0-60.0$ \\
Hohner \& Müller(1965) & 25.9 & $23.1-29.7$ & & 56.3 & $49.5-62.7$ \\
Beer (1976) & 25.5 & $23.1-28.7$ & & 54.8 & $49.9-61.1$ \\
Confalonieri (1983) & 25.8 & $22.8-31.6$ & & 54.6 & $44.8-60.3$ \\
Fernandes et al. (2005) & 26.2 & $25.0-27.1$ & & 54.5 & $53.5-55.7$ \\
\hline
\end{tabular}

TABLE III

Measurements of Trichuris suis eggs $(\mu \mathrm{m})$ registered by other authors

\begin{tabular}{lccccc}
\hline \multirow{2}{*}{ Authors } & \multicolumn{2}{c}{ Width } & & \multicolumn{2}{c}{ Length } \\
\cline { 2 - 3 } \cline { 5 - 6 } \cline { 5 - 6 } & Mean & IC 95\% & & Mean & IC 95\% \\
\hline Dinnik (1938) & 29.6 & $25.0-37.5$ & & 62.0 & $57.5-67.5$ \\
Sondak (1948) & 27.8 & $25.0-30.0$ & & 61.0 & $57.0-68.0$ \\
Hohner \& Müller (1965) & 28.8 & $26.4-31.4$ & & 64.3 & $56.1-69.3$ \\
Beer (1976) & 30.1 & $26.8-34.5$ & & 62.1 & $46.6-71.2$ \\
Sloss et al. (1994) & 23.4 & $22.5-25.4$ & & 55.6 & $50.0-60.0$ \\
\hline
\end{tabular}

and animal trichurids (Table I, II, III) found in each historic context, it was possible to infer which parasites remained throughout the time of occupation and which were prevalent in a particular period. Moreover, paleoparasitological remains helped to confirm or not the archaeological doubts about the prior function of the structures described based on the architectonic characteristics (Plumier et al. 1997a).

\section{Inferences from the paleoparasitology-archaeology evidences}

\section{Gallo-Roman Period}

From a rectangular cesspit, in the sample $02.436 \mathrm{As}$ caris sp. and Trichuris sp. eggs were recorded. The archaeological field description indicated that the structure was used for discharge of organic rejects confirmed by the presence of a swine skeleton without skull. The archaeologists supposed that the structure should belong to a kind of slaughterhouse. Therefore, there is a high possibility that the eggs were from $A$. suum and T. suis. Two samples were collected from the bottom of a well (samples 01.238 and 01.241). The presence of $O$. equi eggs indicates that the Gaulish settlement had horses and the well was used to discharge all sort of organic matter including animal excrements. Ascaris sp. and Capillaria sp. eggs confirm this evidence.

\section{Carolingean Period}

In accordance to field descriptions the layer of organic sediment from which the sample (02.169) was collected had the usefulness of stuffing the pit-silo and do not represent a period of utilization. Ascaris sp., Trichuris sp., and Capillaria sp. eggs were found. Capillaria eggs presented a spotted and plain ornamentation of the shell (Fig. 4) and its measurements $(24 \times 50 \mu \mathrm{m})$ also are compatible with those of poultry and wild birds, although the egg's shell ornamentation is not commented (Levine 1968). So, we can infer that the structure probably was filled with all sort of material including an organic one. There was contamination of human and animal feces.

\section{XI (1055 AD) - XII (1100 a.d.) centuries}

Paleoparasitological findings from the cesspit (samples 04.067 and 04.064) confirm the archaeological record of an

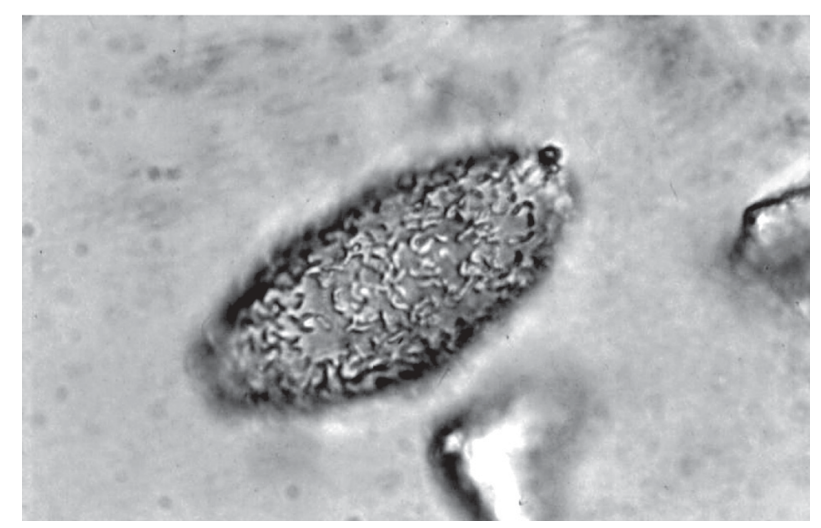

Fig. 4: Capillaria sp. egg $(24 \times 50 \mu \mathrm{m})$, magnification size $400 \times$. Sample 02.169 (Rocha 2003). 


\section{TABLE IV}

Archaelogical structures and parasite finds in "Place d'Armes" archaeological site, Namur, Belgium, from the Gallo-Roman Period through XIX century

\begin{tabular}{|c|c|}
\hline Structures & Samples and paleoparasitological findings \\
\hline \multicolumn{2}{|c|}{ Gallo-Roman Period (II and III centuries AD) } \\
\hline $\begin{array}{l}\text { (Z02 F144) Cesspit } \\
\text { (Z01 F75)Well }\end{array}$ & $\begin{array}{l}\text { 02.436: Ascaris suum; Trichuris suis } \\
\text { 01.238: Ascaris sp.; Oxyuris equi } \\
\text { 01.241: Ascaris sp.; Capillaria } \mathrm{sp.}\end{array}$ \\
\hline \multicolumn{2}{|c|}{ Carolingean Period. IX - XI (1055 AD) centuries } \\
\hline (Z02 F5) Pit-silo & 02.169: Ascaris sp.; Trichuris sp.; Capillaria sp. \\
\hline \multicolumn{2}{|c|}{ XI (1055 AD) - XII (1100 AD) centuries } \\
\hline $\begin{array}{l}\text { (Z04 F106) Latrine } \\
\text { (Z04 F90) Cesspit } \\
\text { (Z01 F37) Cesspit }\end{array}$ & 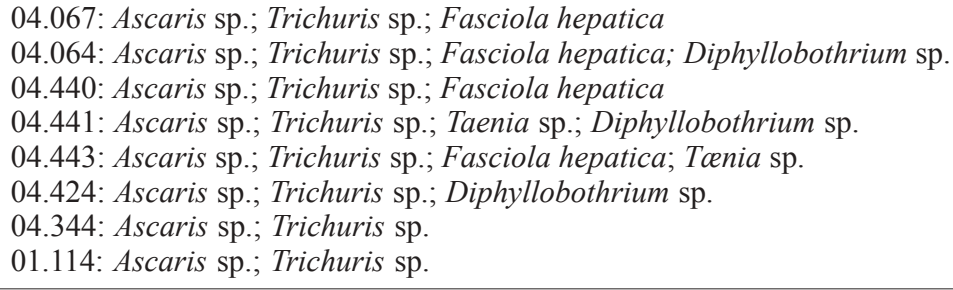 \\
\hline \multicolumn{2}{|r|}{ XII and XIII centuries } \\
\hline $\begin{array}{l}\text { (Z04 F30) Canalization } \\
\text { (Z04 F22) Latrine } \\
\text { (Z04 F110) Latrine } \\
\text { (Z01 F58)Latrine }\end{array}$ & $\begin{array}{l}\text { 04.088: Ascaris } \mathrm{sp} . ; \text { Capillaria } \mathrm{sp} . \\
\text { 04.432: Ascaris } \mathrm{sp} \text {.; Trichuris } \mathrm{sp} . \\
\text { 04.438 Ascaris } \mathrm{sp} \text {; Trichuris } \mathrm{sp} \text {; Taenia } \mathrm{sp} \text {. } \\
\text { 01.248: Ascaris sp.; Trichuris } \mathrm{sp} . \\
\text { 01.252: Ascaris } \mathrm{sp} . ; \text { Trichuris } \mathrm{sp} .\end{array}$ \\
\hline \multicolumn{2}{|r|}{ XIV $-X V$ centuries } \\
\hline $\begin{array}{l}\text { (Z01 F71) Latrine } \\
\text { (Z01 F65) Latrine } \\
\text { (Z04 F56) Barrel } \\
\text { (Z04 F129) Barrel } \\
\text { (Z04 F1) Barrel }\end{array}$ & 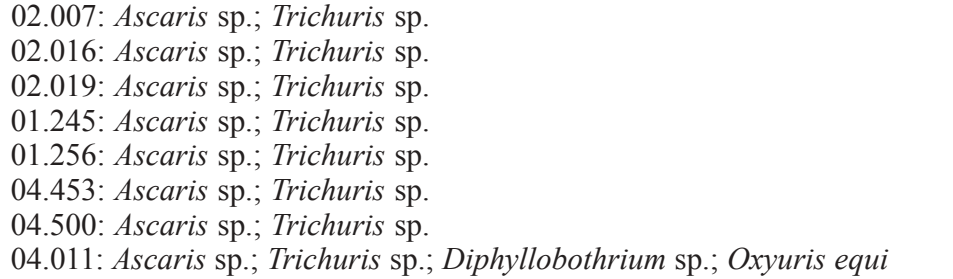 \\
\hline
\end{tabular}

The Renaissance: XV - XVII (1618 AD) centuries

(Z04 F25) Latrine

(Z04 F60)Latrine

(Z01 F72) Latrine

(Z01 F16) Latrine

(Z01 F29) Cesspit
04.333: Ascaris sp.; Trichuris sp.; Fasciola hepatica

04.277: Ascaris sp.; Trichuris sp.

04.269: Ascaris sp.; Trichuris sp.; Taenia sp.

01.219: Ascaris sp.; Trichuris sp.

01.105: Ascaris sp.; Trichuris sp.; Taenia sp.

04.101: Trichuris sp.

Modern Times: XVII (1611 A.D.) - XIX (1828 AD) centuries

(Z04 F128) Latrine

(Z04 F54) Latrine

(Z04 F48) Latrine

04.499: Ascaris sp.; Trichuris sp.

04.259: Ascaris sp.; Trichuris sp.; Taenia sp.

04.300: Ascaris sp.; Trichuris sp.; F. hepatica; Diphyllobothrium sp.

organic layer containing straw, manure and, in addition, traces of stabled animals around the structure. F. hepatica eggs passed through feces of natural hosts, such as bovine, goat, and sheep, and are rarely found in humans. Diphyllobothrium sp. infects humans by raw fish consumption (Acha \& Szyfres 2005, Rey 2001). The cesspit could have been used also for human excrements discharge but it was used mainly for all kinds of discharge of animal origin, according to archaeologists.
The three samples collected from any respective layer attest the organic content of the sediments, confirming their use as a latrine (Z04 F85). The finding of Taenia sp. (whether T. saginata or T. solium) eggs confirms fecal human origin. Both Taenia species are transmitted by raw meat consumption. Raw fish consumption was inferred by the finding of the other Taenidae eggs find, a Di-phyllobotrium species. These Taenid species that infect humans larvae were present in vertebrate 
muscles, being transmitted by raw food. T. trichiura infection was diagnosed by egg measurements, and $A$. lumbricoides eggs inferred by their association with those of T. trichiura (samples 04.443 and 04.424).

In spite of records of poultry bones in the organic layer (sample 04.344) we have found only Ascaris sp. and Trichuris sp. eggs. The cesspit may be used for domestic rejections, including human and animal excrements. The sample 01.144 revealed the same parasites confirming the strong evidence of fecal matter in the sediment.

\section{XII - XIII centuries}

Ascaris sp. and Capillaria sp. eggs were recorded in sediment collected (sample 04.088) from a tubular structure, suggesting a sewerage structure. No other paleoparasitological inference could be done, but these findings represent animal excrement contamination. The following samples $(04.432,04.438$, and $01.248,01.252)$ revealed the classical parasitic association (Ascaris sp. and Trichuris sp.). The human origin of the organic matter (sample 04.438, latrine Z04 F110) was confirmed by both evidences, paleoparasitological (Taenia sp.) and archaeological (the architectonic characteristic).

Latrine Z01 F58 presented two contexts for its function. The parasite eggs retrieved from the sample 01.252 (collected from the bottom) confirm its prior utilization as latrine but the upper layer (sample 01.248) presented other organic traces as bones and even skeleton of dogs and bovines. Therefore, during its earlier utilization the structure was used as a real cesspit receiving all kind of household rejection and probably human and animal feces. Egg measurements confirm the diagnosis (samples 04.432, 04.438 and 01.252 ) of A. lumbricoides and T. trichiura, both of human origin.

\section{XIV - XV centuries}

A rectangular latrine (Z02 F1) was called as "tin pit" by the archaeologists. They have found a tin piece of furniture, rare to the period, representing a wealthy social life of the residents. A variety of archaeological material was also found in the structure, as dog and poultry skeletons, domestic rejections, mainly at the earlier layer (sample 02.007), which could indicate a new function as garbage dump. The three samples revealed Ascaris sp. and Trichuris eggs. Trichurid egg measurements (sample 02.007 ) point to human fecal origin, and consequently $A$. lumbricoides association.

Sample 01.245 represents the layer of utilization of a smaller and simple latrine. Field description estimates the social life and the number of users by its measurements. Ascaris sp. and Trichuris eggs were found and based upon these descriptions human origin of the fecal material may be inferred.

Another latrine (Z01 F65) was used as a cesspit, as showed by the encountering of kitchenware, poultry, swine, rodents, fish and cat skeletons. Ascaris sp. and Trichuris eggs could be of human or other animal origin.

The three barrels found in an urban fosse are known as tonwaterpuit de Raversijde (Bouchet 1995b). These structures were common at this period and used as pit or latrine in the dwelling backyard. Ascaris sp. and Trichu- ris eggs were recorded from two barrels (samples 04.453 and 04.500). Egg measurements indicate that the fecal matter was of human origin. The third sample (barrel Z04 F1) presented the same classic parasitic association, and also Diphyllobothrium sp. and Oxyuris equi eggs. These two parasites indicate the raw fish consumption and the presence of horses. The barrel was then used as a cesspit for human and animal excrement discharge.

\section{The Renaissance: XV - XVII (1618 AD) centuries}

Six samples were collected representing a wealthy square area, called Saint-Remy, totally urbanized and with a trade vocation (Plumier et al. 1997a). Ascaris sp., Trichuris sp., and $F$. hepatica eggs were recovered from a latrine (Z04 F25) attached to a noble familial house. In this sense, an oral-fecal transmitted human infection was evidenced; where water and vegetable contaminated ingestion and no hygiene care contributed to maintain transmission.

Latrine Z04 F60 had a complex stratigraphical structure and was studied in two levels of utilization. At the first one, dated to the XIV century (sample 04.277 collected from the bottom), Ascaris sp. and Trichuris eggs were found confirming the organic texture of the layer. The one dated to XVcentury (04.269) presented evidences of human feces by the recovery of Taenia sp. eggs. A. lumbricoides and T. trichiura eggs were also recorded. The same inference was done to the sample 01.105 (Z01 F16). This latrine replaced a smaller one (Z01 F72) where Ascaris sp. and Trichuris sp. eggs were recovered. The context also indicates human excrements in the sediment. The sixth sample (04.101), from a cylindrical and depth cesspit revealed just Trichuris sp. eggs. The sediment at this level presented traces of poultry skeleton, indicating a domestic structure for rejects.

\section{Modern Times: XVII (1611 AD) - XIX (1828 AD) centuries}

At that time, southern dwellings began to give place to a large square called "Place d'Armes", and a northern community appeared building stables, wood stock, a chapel, and communal prisons. Sample 04.499 was collected from a circular latrine (a typical structure of the XVII century) belonging to a communal house. Ascaris sp. and Trichuris sp. eggs were found. Archaeologists had questioned about the probable multifunction of the structure. Human or animal origin for parasite finds could not be defined, and a mixed domestic discharge may be used.

Sample 04.259 showed Taenia sp. eggs. The respective structure was a typical sewer pit (XVIII century), and belonged to the prison cells area. Raw swine or bovine meat was not the privilege of wealthy people but the lower social strata too, as showed by this find. However, it could be just a communal director privilege. Anyway the fact is that A. lumbricoides, T. trichiura, and Taenia sp. were present.

The last sample (04.300) of the site was dated to the XVI century latrine, related to the prison cells and to the medieval tower. The structure was restored and used lately. The sediment contained an organic texture and ceramic artifacts were also recovered. The findings of Ascaris sp., 
Trichuris sp., F. hepatica, and Diphyllobothrium sp. eggs attest the archaeological suspects of the existence of a fecal matter deposit. Human and animal feces deposit was confirmed.

\section{Paleoepidemiological inferences}

During the Neolithic (9000 BC), plant and animal domestication were developed and human groups turned to sedentary habits establishing closed relationships with animal parasites (Diamond 2002). "Parasites are necessary but not sufficient condition to launch a parasitic disease" (Ferreira 1973).

During the Gallo-Roman Period cesspits were used for animal organic matter discard (carcass, viscera and excrements) and human (excrements). Dried wells were utilized as cesspits, but animal rejects along their prior utilization could also contaminate these structures. Latrines were used as its prior function in the Antiquity as discharge of human excrements. The interaction with Roman culture characterizes the Gallo-Roman period including all of hygiene concepts. Throughout the Middle-Age period many of these concepts were forgot. The notion of the origin of parasitic diseases, in general, was more misunderstood than that in Antiquity Times (Blancou 2000). Latrines received all sort of rejection as domestic garbage, human excrements and animal's remains. Garbage dumps (cesspools) were excavated structures around the villages and used to discard all kind of rejections. Latrines assume the function as sanitary privies from the XVIII century (Monestier 1997).

The parasitic association Ascaris sp. and Trichuris sp. was found along the seven historic contexts at "Place d'Armes" site (Fig. 6). Actually, the same association was found in other paleoparasitological studies as described by Taylor (1955), Pike (1967), Greig (1981), Bouchet (1994, 1995a,b), Bouchet and Paicheler (1995), Aspöck et al. (1973, 1995, 1996); Bouchet et al. (2003b), Gonçalves et al. (2003), Fernandes et al. (2005). Ascariasis and trichuriasis have a direct mechanism of infection, fecal-oral, and human infections are prevalent in population where sanitation conditions are poor (Acha \& Szifres 2005). Although these parasites are host-specific (A. lumbricoides and T. trichiura in humans; A. suum and T. suis in swines), it is experimentally possible the cross-infection between these hosts (Takata 1951, Crewe \& Smith 1971, Beer 1976, Lord $\&$ Bullock 1982). Therefore, it is possible that humans could have been infected by whipworms of pig origin. However, this is not common in present day populations. Cross-infections were recorded for A. suum (Barry \& O'Rourke 1967, Giuffra et al. 2000), but, as for T. suis, it is also rarely found.

Some paleoparasitological findings indicate both the zoological origin of the organic matter and suggest the dietary behavior of a considered settlement or population. Taenia sp., Fasciola hepatica and Diphyllobothrium sp. eggs found, mainly, during the Middle-Age period (Jansen \& Over 1962, Herrmann 1987, Bouchet et al. 2001) testify the under-cooked and nearly raw meat; contaminated vegetables and raw fish consumptions (Acha \& Szifres 2005). Such observations reinforce the historic context and the medieval sanitation conditions. This pe- riod is characterized by an increasing of the urban population concentrated around or inside the fortified villages, with a high dwelling density, space reducing and by the presence of domestic animals very closed, and even inside the domiciles (Rosen 1994, Monestier 1997). The absence of $F$. hepatica or de Taenia sp. eggs, for instance, during the Gallo-Roman Period at "Place d'Armes" site does not mean that the population and animals did not hosted the parasite and did not ingested raw meat. Jansen and Over (1962) found these parasites in Gallo-Roman sites. Bouchet (1995a) observes that since the Gallo-Roman Period, in France, watercress (Nasturtium officinale) was much appreciated even actually. Other parasitic marker that contributed to define the presence of animal excrement was the finding of $O$. equi eggs (Fig. 5). It is a hostspecific parasite of equine that reveal the existence of stabled animals at the settlement.

In general, these three parasites were found in archaeological contexts related to a wealthy and noble people, especially Taenia sp. and Diphyllobothrium sp. (Bouchet 1995a, Bouchet \& Paicheler 1995, Bouchet et al. 1998, 2003b). In France, the poor people used to eat a soup prepared with small fragments of well-cooked meat called ragout (Bouchet et al. 2003b). We have found Taenia eggs

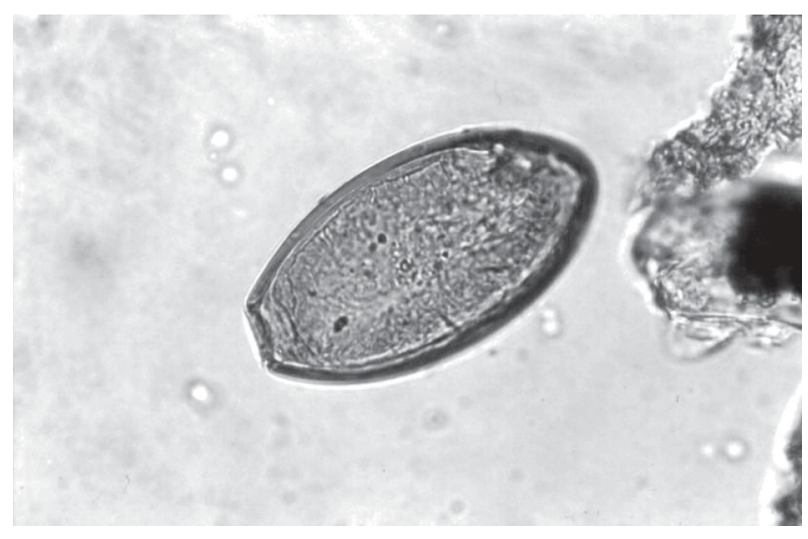

Fig 5: Oxyuris equi egg $(42 \times 80 \mu \mathrm{m}), 600 \times$. Sample 04.011 (Rocha 2003).

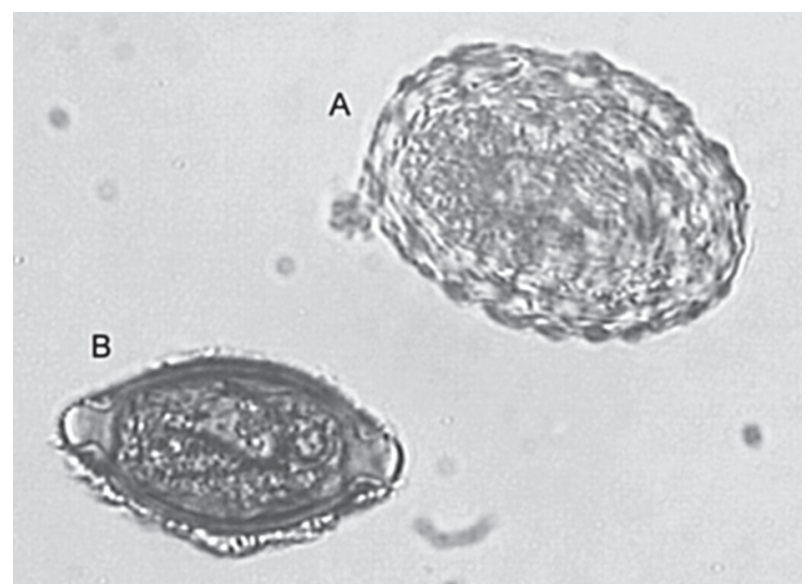

Fig. 6A: Ascaris sp.; B: Trichuris sp. eggs found throughout the archaeological site of Namur, Belgium (Rocha 2003). 
into the sediments collected from a prison cells area, in recent time, at the "Place d'Armes" site. Maybe, we must reconsider or require additional archaeological information about the context observed in Namur.

In spite of the retrieve of Capillaria sp. eggs is necessary to emphasize that this parasite were found abundantly since the Neolithic (Bouchet 1997, Bouchet et al. 1997). The parasite is widespread and affects especially domestic and synanthropic animals (poultries, swine, sheep, goats, dogs, cats, rodents, and rabbits). The humans are rarely infected but when it occurs, in general, are due to the absence of hygiene care (Acha \& Szifres 2005). We consider that the findings at the site probably occurred by animal excrements contamination but further observations must be done.

\section{Final considerations}

Different kinds of deposits provide a dry and anaerobic microenvironment and consequently suitable conditions for preservation of helminth eggs. A weak constitution of the eggshell might determine its decay due to taphonomic processes. Sediment analyses are also considered by taphonomic studies that characterize the process, and used to study different phases of decay and how reintegration of organic matter to the ground occurs. Such analyses contribute to identify the remains of paleoparasitological and/or archaeological interest (Ubelaker et al. 2002). Also, the sediments must be analyzed under a previous geological approach to reconstitute those taphonomic levels of the parasitic developmental stages present (Bouchet et al. 1995). Paleoparasitological analyses must consider possible ultra structural changes that may alter morphometric parameters of helminth eggs (Bouchet et al. 1999). We emphasize the importance of recovering samples all around at the collect point to permit a comparison in the same stratigraphical layer. In many cases, the water influx or recent contamination could alter an intact strata setting. So it is important recovery samples in different strata (Bouchet \& Bentrad 1997, Bouchet et al. 1999, 2003b). In addition, it must be certified that the samples were retrieved from a disturbed or not disturbed setting. Furthermore, adequate technical care of collecting must be applied (use of gloves) to avoid contaminating samples. It is important, mainly if the material will be submitted to DNA analyses (Loreille \& Bouchet 2003, Bouchet et al. 2003b).

Associated material provides very important additional information about the setting. For instance, a high concentration of a helminth eggs associated to seeds and pollen represents a strong trace of alimentary origin of the layer under analyses. Archaeological artifacts also help to understand the paleoparasitological context. The architectonic characteristics of the structures are so important to the archaeological context permitting to differentiate and establish the correct origin of the fecal matter. Thus, much more multidisciplinary information about the settle much better will be the paleoparasitological approaches.

\section{Conclusions}

Up to recent periods of the settlement paleoparasitological remains revealed a secular parasitic association (Ascaris sp. and Trichuris sp). In accordance to the sanitation conditions presented along the historic context one can consider cross infection between human and animal population. When host-specific parasites were present it was possible to confirm the zoological origin of the organic sediments and associated with the archaeological contexts we could infer about the prior function of the deposits. Although paleoepidemiological inferences could not be estimated for all the occupational layers, it is interesting to note sequences of parasites throughout the periods of the "Place d'Armes" site.

\section{REFERENCES}

Acha PN \& Szyfres B 2005. Zoonoses et Maladies Transmissibles Communes à l'Homme et aux Animaux, 3rd ed., Office International des Epizooties, Paris.

Araújo A, Ferreira LF 2000. Paleoparasitology and the antiquity of human host-parasite relationships. Mem Inst Oswaldo Cruz 95 (Suppl. 1): 89-93.

Araújo A, Jansen AM, Bouchet F, Reinhard K, Ferreira LF 2003. Parasitism, the diversity of life, and paleoparasitology. Mem Inst Oswaldo Cruz 98 (Suppl.1): 05-11.

Araújo A, Reinhard K, Bastos OM, Costa LMC, Pirmez C, Iñiguez A, Vicente AC, Morel CM, Ferreira LF 1998. Paleoparasitology: perspectives with new techniques. Rev Inst Med Trop São Paulo 40: 371-376.

Aspöck H, Auer H, Picher O 1995. The mummy from the Hauslabjoch: a medical parasitology perspective. Alpe Adria Microbiol J 2: 105-114.

Aspöck H, Auer H, Picher O 1996. Trichuris trichiura eggs in the Neolithic glacier-mummy from the Alps. Parasitol Today 12: 255-256.

Aspöck H, Auer H, Picher O 1999. Parasites and parasitic diseases in prehistoric human populations in Central Europe. Helminthology 36: 139-145.

Aspöck H, Flamm H, Picher O 1973. Darmparasiten in bergwerken der Hallstatt-Kultur (800-350 v. Chr.). Zlb Bakt Hyg I Ab Orig 223: 549-558.

Barry JM, O’Rourke FJ 1967 Apud Loreille O \& Bouchet F 2003. Evolution of Ascariasis in humans and pigs: a multidisciplinary approach. Mem Inst Oswaldo Cruz 98 (Suppl. 1): 39-46.

Beer RJS 1976. The relationship between Trichuris trichiura (Linnaeus 1758) of man and Trichuris suis (Schrank 1788) of the pig. Res Vet Sci 20: 47-54.

Blancou J 2000. Histoire de la Surveillance et du Controle des Maladies Animales Transmissibles, Office International des Épizooties, Paris.

Bouchet F1991a. Etude parasitologique: recherche des oeufs d'helminth dans les fosses et dépotoirs du site des jardins du Carrousel. In P Van Ossel, Les Jardins du Carrousel à Paris, Fouilles 1989 - 1990. III. Les Rapports des Spé-cialistes, p. 165-171.

Bouchet F 1991b. Etude parasitologique des chantiers archéo- 
logiques de Beauvais (Oise). Rev Archéol Picardie 3/4:293-294.

Bouchet F 1994. Analyse parasitologique des Logis de la Cour des Suisses. Archéologia: les dossiers d'archéologie 190: 92-93.

Bouchet F 1995a. La paléoparasitologie au Grand Louvre. Bul d'Association des Anciens Eléves de l'Institute Pasteur, $37^{\circ}$ anné 143: 8-11.

Bouchet F 1995b. Maladies parasitaires identifiées dans le remplissage d'une latrine à tonneau au village déserté de Walraversijde (ville d'Ostende, prov. de Flandre Occidentale). In M Pieters, Een $15^{\text {de }}$-eeuwse sector van het verdwenen vissersdorp te Raversijde (stad Oostende, prov. West-Vlaanderen). Interimverslag 1994, Archeologie in Vlaanderen IV, p. 234-235.

Bouchet F 1997. Intestinal capillariasis in neolithic inhabitants of Chalain (Jura, France). Lancet 349: 256.

Bouchet F, Bentrad S 1997. Recovery of equine helminth eggs in a medieval lacustrine settlement. Vet Rec 141: 601-602.

Bouchet F, Paicheler JC 1995. Paléoparasitologie: présomption d'un cas de bilharziose au $\mathrm{XV}^{\mathrm{e}}$ siècle à Montbéliard (Doubs, France). Centre de Recherche d'Academie de Sciences de Paris, Sciences de la Vie 318: 811-814.

Bouchet F, Audoin F, Leger N, Marchais R, Baucheron F, Munoz la Casta J 1989. Etude parasitologique des coprolites et des sediments de trois ensembles clos medievaux de la rue de Lutèce (Ile de la Cité) à Paris. Rev Archéom 13: 13-21.

Bouchet F, Bentrad S, Dommelier S, Paicheler JC, Pétrequin P 1997. Capillarioses intestinales: nématodose du Néolitique? Bull Soc Fr Parasitol 15: 49-54.

Bouchet F, Bentrad S, Paicheler JC 1998. Enquête épidémiologique sur les helminthiases à la cour de Louis XIV. Médicine/Sciences 14: 463-466.

Bouchet F, Bentrad S, Martin C 2001. Apud Bouchet F, Harter S, Le Bailly M 2003c. The State-of-the-art of paleoparasitological research in the Old World. Mem Inst Oswaldo Cruz 98 (Suppl.1): 98-101.

Bouchet F, Harter S, Paicheler JC, Araújo A, Ferreira LF 2002. The first recovery of Schistosoma mansoni eggs from a latrine in Europe $\left(15^{\text {th }}-16^{\text {th }}\right) . J$ Parasitol 88: 404-405.

Bouchet F, Harter S, Le Bailly M 2003b. The State-of-the-Art of paleoparasitological research in the Old World. Mem Inst Oswaldo Cruz 98 (Suppl.1): 98-101.

Bouchet F, Guidon N, Dittmar K, Harter S, Ferreira LF, Chaves SAM, Reinhard K, Araújo A 2003a. Parasite remains in archaelogical sites. Mem Inst Oswaldo Cruz 98 (Suppl.1): 47-52.

Bouchet F, Lavazec C, Nattier V, Dommelier S, Bentrad S, Paicheler JC 2000. Etude de la parasitofaune du site médiéval de Charavines (Lac de Paladru, Isère, France). Bull Soc Zool Fr 125: 205-215.

Bouchet F, Lefèvre C, West D, Corbett D 1999. First paleoparasitological analysis of a midden in the Aleutian Island (Alaska): results and limits. J Parasitol 85: 369-372.

Bouchet F, Pétrequin P, Paicheler JC, Dommelier-Spejo S 1995. Première approche paléoparasitologique du site néolithique de Chalain (Jura, France). Bull Soc Pathol Ex 88: 265-268.
Buckland W 1829. On the discovery of coprolites, or fossil faeces, in the Lias at Lyme Regis and in other formations. Trans Geol Soc London, Series II.3, part I: 223-236.

Callen EO, Cameron TNM 1960. A prehistoric diet revealed in coprolites. New Sci 8: 35-40.

Confalonieri UEC 1983. Paleoparasitologia do Gênero Trichuris Roederer, 1761, com um Estudo Paleoepidemiológico sobre a Origem do Trichuris trichiura (Linn., 1771), Stiles, 1901 na América (Nematoda, Trichuridae), Thesis, Instituto de Biologia, Universidade Federal Rural do Rio de Janeiro, Itaguaí, 170 pp.

Crewe W, Smith DH 1971. Human infection with pig Ascaris (A. suum). Ann Trop Med Parasitol 65: 85.

Diamond J 2002. Armas, Germes e Aço: os Destinos das Sociedades Humanas, 3a. ed., Record, Rio de Janeiro.

Dinnik NN 1938. Independent Species Trichocephalus trichiurus (L., 1771) and Trichocephalus suis (Schrank, 1788). apud UEC Confalonieri 1983. Paleoparasitologia do Gênero Trichuris Roederer, 1761, com um Estudo Paleoepidemiológico sobre a Origem do Trichuris trichiura (Linn., 1771), Stiles, 1901 na América (Nematoda, Trichuridae), Thesis, Instituto de Biologia, Universidade Federal Rural do Rio de Janeiro, Itaguaí, 170 pp.

Dommelier-Espejo S 2001. Contribuition à l'Etude Paléoparasitologique des Sites Néolithiques en Environnement Lacustre dans les Domaines Jurassien et Péri-Alpin, Thesis, UFR de Sciences Exactes et Naturelles, Université de Reims Champagne-Ardenne, Reims, 248 pp.

Fernandes A, Ferreira LF, Gonçalves MLC, Bouchet F, Klein $\mathrm{CH}$, Igushi T, Sianto L, Araújo A 2005. Intestinal parasite analysis in organic sediments collected from $16^{\text {th }}$ century Belgian archeological site. Cad Saú Públ 21: 329-332.

Ferreira LF 1973. O fenômeno parasitismo. Rev Soc Bras Med Trop 4: 261-277.

Ferreira LF, Araújo A, Confalonieri U 1983. The finding of helminth eggs in a brazilian mummy. Trans $R$ Soc Trop Med Hyg 77: 65-67.

Ferreira LF, Araújo A, Confalonieri U 1988. Paleoparasitologia no Brasil, PEC/ENSP, Rio de Janeiro.

Giuffra E, Kijas JMH, Armager V, Carlborg Ö, Jeon JT, Andersson L 2000. The origin of the domestic pig: independent domestication and subsequent introgression. Genetics 154 : 1785-1791.

Gonçalves MLC, Araújo A, Ferreira LF 2003. Human intestinal parasites in the past: new findings and a review. Mem Inst Oswaldo Cruz 98 (Suppl.1): 103-118.

Greig J 1981. The investigation of a medieval Barrel-latrine from Worcester. J Archaeol Sci 8: 265-282.

Grzywinski L 1960. Analysis of feces from the Middle Age Period. Zool Polonica 10: 195-199.

Han E, Guk S, Kim J, Jeong H, Kim S, Chai J 2003. Detection of parasites eggs from archaeological excavations in the Republic of Korea. Mem Inst Oswaldo Cruz 98 (Suppl. 1): 123-126.

Hardesty DL 1977. Ecological Anthropology, Jonh Wiley \& Sons Inc., New York.

Herrmann B 1987. Parasitologische Untersuchung mittelal- 
terlicher Kloaken. Mensh und Umwelt im Mittelalter 3: 160169.

Hohner L, Müller KH 1965. Vergleichende Grössenbestimmungen an Eiern von Peitschenwürmern des Menschen und des Schweines. apud UEC Confalonieri 1983. Paleoparasitologia do Gênero Trichuris Roederer, 1761, com um Estudo Paleoepidemiológico sobre a Origem do Trichuris trichiura (Linn., 1771), Stiles, 1901 na América (Nematoda, Trichuridae), Thesis, Instituto de Biologia, Universidade Federal Rural do Rio de Janeiro, Itaguaí, $170 \mathrm{pp}$.

Iñiguez AM, Araújo A, Ferreira LF, Vicente ACP 2003. Analysis of ancient DNA from coprolites: a perspective with random amplified polymorphic DNA-polymerase chain Reaction approach. Mem Inst Oswaldo Cruz 98 (Suppl. 1): 63-65.

Jansen Jr. J, Over HJ 1962. Het voorkomen van parasieten in terpmateriaal uit Noordwest Duitsland. Tijdschr Diergeneesk 87: 1377-1379.

Jansen Jr. J, Over HJ 1966. Observations on helminth infections in a roman army-camp. Proc 1st Int Congr Parasitol, Roma, 1964, 791 pp.

Jones AKG 1982. Human parasite remains: prospects for a quantitative approach. In AR Hall, HK Kenward (eds), Environmental Archaeology in the Urban Context, Council for British Archaeology, London, p. 66-70.

Jones AKG 1985. Trichurid ova in archaeological deposits: their value as indicators of ancient faeces. In RJ Fieller, DD Gisbertson, NGA Ralph (eds), Paleobiological Investigations: Research Design, Methods and Data Analysis. Symposia of the Association for Environmental Archaeology n. 5b, British Archaeological Reports International series, Heslington, p. 105-119.

Levine ND 1968. Parasites of Domestic Animals and of Man, Burgess Publishing, Minnesota.

Lord WD, Bullock WL 1982. Swine Ascaris in humans. NEngl JMed 306: 113.

Loreille O, Bouchet F 2003. Evolution of Ascariasis in humans and pigs: a multi-disciplinary approach. Mem Inst Oswaldo Cruz 98 (Suppl. 1): 39-46.

Monestier M 1997. Histoire et Bizarreries Socials des Excréments. Des Origins à nos Jours, Le Cherche Midi Éditeur, Paris.

Pike AW 1967. The recovery of parasite eggs from ancient cesspit and latrine deposits: an approach to the study of early parasite infections. In D Brothwell, AT Sandinson (eds) Diseases in Antiquity, CC Thomas Springfied, London, p.184-188.

Pike AW 1968. Recovery of helminth eggs from archaeological excavations, and their possible usefulness in providing evidence for the purpose of an occupation. Nature 219: 303304.

Pike AW, Biddle M 1966. Parasite eggs in Medieval Winchester. Antiquity 40: 293-296.
Plumier HN, Vanmechelen R 1996. "Place d'Armes, Place aux fouilles". L'archéologie namuroise dans le sillage d'un parking souterrain. Namur Magazine 12: 14-15.

Plumier HN, Mees N, Vanmechelen R 1997a. Namur: eléments de topographie urbaine au Bas Moyen Age. In MH Corbiau, Le Patrimoine Archéologique de Wallonie, Namur.

Plumier HN, Vanmechelen R, Dupont C 1997b. Namur, Place d'Armes: opération d'archéologie préventive. In J Plumier, Actes de la Cinquième Journéé d'Archéologie Namuroise 22: 91-94.

Reinhard KJ 1992. Parasitology as an interpretative tool in archaeology. Amer Ant 57: 231-245.

Rey L 2001. Parasitologia, 3rd ed., Guanabara Koogan, Rio de Janeiro.

Rocha GC 2003. Praça das Armas, Namur, Bélgica. Contribuição de um Estudo Paleoparasitológico, Thesis, Escola Nacional de Saúde Pública-Fiocruz, Rio de Janeiro, 145 pp.

Rosen G 1994. Uma História da Saúde Pública, Unesp, São Paulo.

Schia E 1979. Feltene "Oslogate 3 og 7", De arkeologiske utgravninger i gamlebyen Oslo, 2, Øvre Ervik. Apud Jones AKG 1982. Human parasite remains: prospects for a quantitative approach. In AR Hall, HK Kenward (eds), Environmental Archaeology in the Urban Context, Council for British Archaeology, London, p. 66-70.

Specht W 1963. Eine interessante Erdprobe aus einer Abortgrube im Römerkastell Kümzing. Saalburg- Jahrbuch 21: 90-94.

Sloss MW, Kemp RL, Zajac AM 1994. Veterinary Clinical Parasitology, Iowa State University Press, Iowa.

Sondak VA 1948. Independence of the whipworm species Trichocephalus trichiura and the swine whipworm Trichocephalus suis. Parasitol Sbornik 10: 197.

Szidat L 1944. Über die Erhaltungsfähigkeit von Helmintheneiern in vor-und frühgeschichtlichen Moorleichen. Zeitsch Parasit 13: 265-274.

Takata I 1951. Experimental infection of man with Ascaris of man and the pig. Kitasato Arch Exp Med 23: 49-59.

Taylor EL 1955. Parasitic helminths in Medieval remains. Vet Rec 67: 218-228.

Ubelaker H, Ward DC, Braz VS, Stewart J 2002. The use of SEM/EDS analysis to distinguish dental and osseus tissue from other materials. J For Sci 47: 940-943.

Wilke PJ, Hall HJ 1975. Analysis of Ancient Feces: a Discussion and Annotated Bibliography, Archaeological Research Facility, Department of Anthropology, University of California, Berkeley, $47 \mathrm{pp}$.

Wilson A, Rackham DJ 1976. Parasite eggs. In PC Buckland, The Archaelogy of York: The Past Environment of York, the Environmental Evidence from the Church Street Sewer System, Council for British Archaeology, London, p. 32-33. 